\title{
Do Contributions of Islamic Banks Stakeholders Influence Profit and Loss Sharing Financing? : Empirical Evidence in Indonesia
}

\author{
Titin Vegirawati*, Didik Susetyo*, \\ Inten Meutia***, Lukluk Fuadah****
}

Received: 27.08 .2018

Accepted: 21.12.2018

DOI: $10.25272 /$ ijisef.455191

Type: Research Article

\begin{abstract}
The purpose of this study is to examine the influence of contribution of shari'ah bank stakeholders on profit and loss sharing financing, in the case of Indonesia. Stakeholders contributions consisted of Investors, Depositors, Management, and shari'ah supervisory board. 9 Islamic commercial banks and 16 Islamic business units were selected using purposive sampling method. Data obtained from annual reports from 2011 to 2017.

The results of the study with multiple regression models show that stakeholder contributions, such as mudharabah depositors and wadiah depositors as well management have a positive influence on profit and loss sharing financing. Other stakeholder contributions proved to have no significant effect on profit and loss sharing financing.
\end{abstract}

Keywords: Stakeholders Contributions, Financing, Multiple Regression.

Jel Codes: G21, P45, Z12.

\footnotetext{
* IBA University, Economic Faculty, Departement Accounting, email: titinvegirawati@gmail.com, ORCID: https://orcid.org/0000-0002-9195-8796

** Sriwijaya University, Economic Faculty, email: didiksusetyo@yahoo.com, ORCID: https://orcid.org/0000-00022435-3519

*** Sriwijaya University, Economic Faculty, Departmen Accounting, email: inten26@yahoo.com, ORCID: https://orcid.org/0000-0002-2418-0283

**** Sriwijaya University, Economic Faculty, Department Accounting, email: lukluk.fuadah@gmail.com, ORCID: https://orcid.org/0000-0003-2163-9471:
} 


\section{Introduction}

The main foundation underlying Islamic economics is Tawheed. This foundation shows the surrender of all things to God, so that all economic activity is based on obedience to God. This foundation is also a reference for Shari'ah Enterprise Theory. Triyuwono (2007) explained that God is the center of everything. Handayati, Krisnawati, Soetjipto, Sudarmiatin, and Suharto (2017) explained that God has always been the main cause of the conduct of a business. God is also the main owner of all the resources in the world. All resources owned by humans are entrusted by Allah SWT who must be accounted for. Man is chosen by Allah SWT to be a world leader who has a mission to create and distribute prosperity to humanity and nature (Meutia, 2010).

Islamic banks are one form of business established with Allah SWT as a cause of its establishment. This bank was founded by Muslims as a form of devotion to Allah SWT. This bank is a solution for Muslims around the world to establish a foundation of justice and free from the mechanism of interest in the banking system. The interest called riba is prohibited in Islamic law. However, Islamic banks are not established only to avoid bank interest. This bank was built to avoid unethical practices and actively participate in achieving Islamic economic goals and objectives (Ahmed, \& Barikzai, 2016).

An interest-free banking system is run using the basic principles of Islamic finance. The first basic financial principle is risk sharing, where each participant in a transaction must share the profit and the risk of loss from a transaction. The percentage of the distribution of profit or loss to each party that works together has been determined in advance. The second basic principle is No Exploitation, there is no participant in the transaction that should be exploited in the operation (Bakar and Ali, 2008). This means that operations must be interest free (usury), do not contain uncertainty (gharar) and do not contain gambling (Rosly, 2005, Siddiqui, 2008). The third basic principle that must be upheld is that the bank does not give funds to activities that are prohibited in Islamic principles (Rosly 2005; Siddiqui, 2008; Bakar and Ali, 2008).

Three basic principles of Islamic finance become guidelines for Islamic banks in determining various financing products. Financing products are divided into two methods, namely fixed markup method and profit sharing based financing. This classification is based on profit sharing and risk imposition.

The best Islamic bank financing products are profit and loss sharing financing (Ascarya and Yumanita, 2005, Rosly 2005, Chong and Liu, 2009, Hanif and Iqbal 2010, Saad and Razak, 2013, Azmat, Michael and Kym, 2015). In this financing product, two or more parties who are partnering can get a portion of the profit determined in advance. On the contrary, with this product, banks and other stakeholders share risks and do not exploit each other.

Several studies have empirically proven that profit and loss sharing financing has the ability to bring economic benefits by promoting real sector growth (Abduh and Omar, 2012; Saad and Razak 2013). Some research results stated that this financing benefits Islamic banks. Jaurino and Wulandari (2017) have conducted research on the effect of mudarabah financing and 
musharakah financing on bank profitability. The research results obtained with SEM-PLS analysis techniques show the influence of mudarabah financing on the profitability of Islamic banks.

Nevertheless, these facts have not been able to boost the amount of this financing. These two types of profit and loss sharing financing are still a minority financing in Islamic banks (Khan, 1995, Rosly, 2005, Chong and Liu, 2009). The composition of financing by Islamic Banks and Islamic Business Units in Indonesia can be seen in the following table:

Table 1: The Composition of Financing by Islamic Bank and Islamic Business Units in Indonesia

(Billion IDR)

\begin{tabular}{|l|l|l|l|l|l|}
\hline Contracts & $\mathbf{2 0 1 3}$ & $\mathbf{2 0 1 4}$ & $\mathbf{2 0 1 5}$ & $\mathbf{2 0 1 6}$ & $\mathbf{2 0 1 7}$ \\
\hline Mudarabah & 13625 & 14354 & 14820 & 15292 & 17090 \\
\hline Musharakah & 39874 & 49387 & 60713 & 78421 & 101505 \\
\hline Total & $\mathbf{5 3 4 9 9}$ & $\mathbf{6 3 7 4 1}$ & $\mathbf{7 5 5 3 3}$ & $\mathbf{9 3 7 1 3}$ & $\mathbf{1 1 8 5 9 5}$ \\
\hline Murabahah & 110565 & 117371 & 122111 & 139536 & 150331 \\
\hline Salam & 0 & 0 & 0 & 0 & 0 \\
\hline Istisna & 582 & 633 & 770 & 878 & 1188 \\
\hline Ijarah & 10481 & 11620 & 10635 & 9150 & 9230 \\
\hline Qardh & 8995 & 5965 & 3951 & 4731 & 6349 \\
\hline Others & 0 & 0 & 0 & 0 & 0 \\
\hline Total & $\mathbf{1 3 0 6 2 3}$ & $\mathbf{1 3 5 5 8 9}$ & $\mathbf{1 3 7 4 6 7}$ & $\mathbf{1 5 4 2 9 5}$ & $\mathbf{1 6 7 0 9 8}$ \\
\hline Financing Total & $\mathbf{1 8 4 1 2 2}$ & $\mathbf{1 9 9 3 3 0}$ & $\mathbf{2 1 2 9 9 9}$ & $\mathbf{2 4 8 0 0 8}$ & $\mathbf{2 8 5 6 9 3}$ \\
\hline
\end{tabular}

Source : Shari'ah Banking Statistics, Financial Services Authority, December 2017

The above table shows the amount of profit and loss sharing financing consisting of Mudarabah and Musharakah continues to increase. But in total, this financing is not dominant so it has not become the main product of Islamic banks. From 2013 to 2017, profit and loss sharing financing are distributed ranged from 29.05 percent to 41.51 percent, while fixed mark-up based financing ranged from 58.49 percent to 70.94 percent. These phenomena indicated that Islamic banks have not taken optimal action to become ideal Islamic banks.

Banks must prioritize the interests of all stakeholders of Islamic banks. They must realize that these bank stakeholders have different characteristics from stakeholders in conventional banks. Stakeholders in this bank keep the religious values behind their business activities.

Islamic bank stakeholders want financial benefits and non-financial benefits. Dusuki (2008) examined 1541 Shari'ah Bank stakeholders in Malaysia. The results of his research concluded that stakeholders expected the Shari'ah Bank to prioritize the promotion of Islamic values and a way of life for staff, clients and the general public. The study results also suggested that 
stakeholders want Islamic banks contribute to the social welfare of the community, promoting sustainable development projects and poverty alleviation.

The results of this study also explain the expectations of all stakeholders in Islamic banks in Malaysia. Judging from their expectations, the stakeholders of Islamic banks are divided into two groups. The first group is the users of funds, customers, employees and the local community. This group consistently hopes that Islamic banks choose ideal financing in the form of profit sharing based financing. The second stakeholder group is bank managers, shari'ah advisers and regulators. This second group expects banks to be able to maintain business continuity and resilience so that they can become competitive banks. The results of this study illustrate the different expectations and interests between agents and principals in Islamic banks. According to agency theory (Jensen and Meckling, 1976) these differences in interests motivate bank agents or managers to take actions that are different from their principal interests.

Despite facing agency problems as well as companies in general, Islamic banks have Islamic values that are unique identities and become unifying stakeholders in achieving business goals and purposes of worship (Al-shamali et al., 2013). Stakeholder Theory explains that stakeholders contribute together to provide the resources they have to the companies chosen to achieve common goals (Freeman, 2010). The management of a company that is trusted must be the protector of their interests. The attention and protection of the company to the interests of all parties must be balanced, so that no key stakeholders benefit more than other stakeholders (Donaldson et al., 1995).

\section{Literature Review}

\subsection{Stakeholder Theory}

The Bank is one type of company, which consists of several stakeholders. Each stakeholder works together, competes and has intrinsic value. Stakeholder theory explains that all stakeholders are linked so as to form the organizational framework used in strategic management. The organizational framework shows that there is a reciprocal relationship for each stakeholder, as long as they can influence each other in obtaining benefits and losses such as rights and obligations. Each stakeholder has an interest that varies according to the type of company. Freeman (2002 and 2010) explains that stakeholders contribute to the company.

The owner of the capital invests in the form of shares by expecting a return on capital. Employees have expertise, as a return, they expect the company to provide security, salaries, benefits and meaningful work. Suppliers interpreted in stakeholder theory are important for the success of the company, providing raw materials that can determine the quality and the price of the final product. Consumers exchange resources for products from companies and instead receive product benefits. 
Stakeholders in the company can be seen in the following figure:

Figure 1: A stakeholder model of the corporation

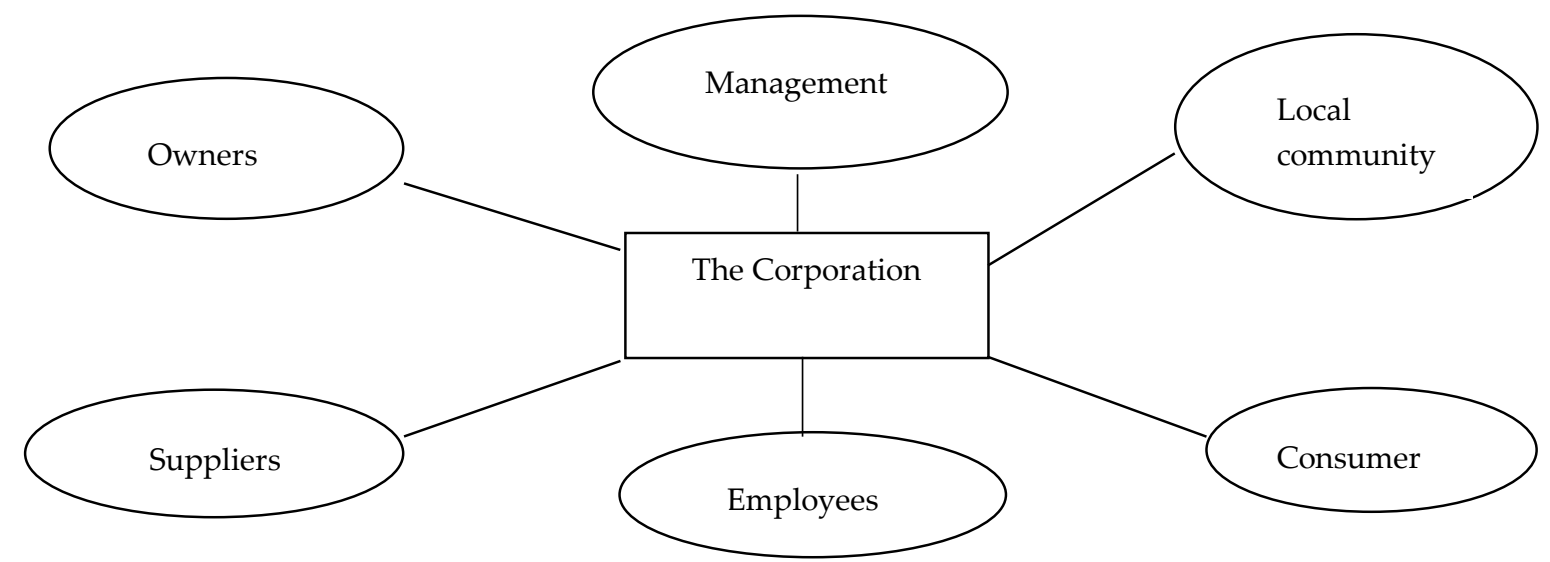

Source: Freeman,R. E.(2002)

The local community guarantees the company's right to build facilities and conversely the community will obtain various benefits in the form of tax rates, economic and corporate social contributions. Management plays a special role as an employee with several explicit and implicit work contracts. In addition, management has the duty to guarantee the abstract welfare of the entity. Management, especially top management must pay attention to the health of the company, including the balance of many claims from conflicts of interest. Capital owners want higher profits, while consumers want companies to invest more funds for research and development. Employees want higher salaries, while communities want better parks and maintenance facilities.

Stakeholder theory does not only discuss relationships between stakeholders in an organization or company. This theory combines business with ethics or moral values, so there are no dominant stakeholders. All parties are treated fairly, both those who have direct and indirect financial relations.

Stakeholder theory is very appropriate if it is used to explain the phenomena that occur in Islamic banks. Islamic banks view their stakeholders as interconnected parties. Stakeholders not only expect benefits from the contributions they contribute. They prioritize the use of Islamic values as the basis of all their business activities.

Al-shamali et al. (2013) explained the application of stakeholder theory to Islamic banks caused by two key factors. First, the tendency of increasing the scale of Islamic banks that has been and will continue to be felt by stakeholders, so that their reputation is increasing as well. The second key factor relates to morality in Islamic banks. The purpose of stakeholder theory is to create awareness and accountability that banks have internal and external stakeholders, so that the responsibility of Islamic banks is not only focused on annual profits, but also on the welfare of all stakeholders. 
Although each stakeholder has a different identity, it does not mean to be perfectly independent and cannot influence his views and thoughts. Stakeholder theory in an Islamic perspective explains, when an Islamic identity is viewed, the influence of differences in stakeholders decreases and the identity of the bank becomes clear and communicated through large networks within and outside the bank. Thus the interpretation of stakeholders of Islamic banks can be extracted with the Islamic identity (Al-Shamali et al., 2013).

Islamic banks consist of consumers, customers, local communities, employees, managers, regulators and shari' ah supervisory boards (Agriyanto, 2015). The shari'ah supervisory board is a stakeholder that only exists in Islamic banks. This board serves to provide compliance assurance of products and services offered to customers and investors towards shari'ah rules and principles (Hamza, 2013).

\subsection{Shari'ah Enterprise Theory}

Shari' ah Enterprise Theory (SET) is a theory that states that Allah is the center of everything. Humans as God's representatives must obey all the laws of Allah (Handayati et al., 2017). This theory shows that institutions are not only responsible to horizontal stakeholders, but also have vertical responsibilities, namely to God (Kurniawati \& Yaya, 2017).

Triyuwono (2007) explains that each institution is owned by a broad stakeholder. Stakeholders of an institution are Allah SWT, man and Nature. Allah SWT is the highest stakeholder and is the only goal of human life. The second stakeholder described in this theory is direct stakeholders and indirect stakeholders. Direct stakeholders are stakeholders who provide financial and non-financial contributions. These stakeholders have the right to obtain welfare from their institutions. Conversely, indirect stakeholders are stakeholders who have no contribution to the institution. However, they have shari'ah rights to get welfare from the institution (Novarela \& Sari, 2015).

This theory explains that Allah SWT, the owner of all the resources in the world, gives a mandate to humans as khalifatullah fil ardhi (Triyuwono, 2007). Humans who act as caliphs have a noble mission to create and distribute welfare for all humans and the universe (Kalbarini \& Suprayogi, 2014). Humans as trustees will certainly distribute welfare in accordance with the wishes of the true owner of all resources, namely Allah SWT. Such distribution will ensure fair distribution, risk sharing and no element of exploitation.

\subsection{Empirical Research}

Several studies have been conducted related to this research, both conducted in Indonesia and in other countries. Dusuki (2008) surveyed the views of seven stakeholder groups at Bank Syariah Malaysia Berhad and Bank Muamalat Malaysia Berhad. Data collection was done using questionnaires sent or given directly to 1780 respondents. The results of the study show that the first group consisting of employees, financing users and depositors believes that Islamic banks must realize themselves as ideal Islamic banks by applying the Profit and Loss Sharing Financing instrument. On the other hand the second group consisting of bank 
managers, regulators and shari'ah advisors generally concentrated more on the sustainability and resilience of the bank's business. in this way this second group considers banks to be more competitive.

Ascarya (2010) conducted a study of the factors that led to the lack of profit sharing based financing for Islamic Banks. This study used the Analytic Network Process (ANP) method, which is to understand and imagine the problem as a whole. The results showed the lack of profit-based financing due to two aspects, namely internal aspects and external aspects. Internal aspects relate to the lack of information technology, standard operating procedures and management commitment. While the external aspects that also led to this lack of financing were the lack of government commitment and the support of legislators and the lack of public trust and understanding of this financing.

In Pakistan, Farooq \& Ahmed (2013) also conducted research on musharakah financing. The results showed that one of the factors that led to slow-growing musharaka financing was management's commitment. Management is less interested in this financing.

Various obstacles must be faced by Islamic banking to become the ideal Islamic banking. This banking must unite all stakeholders to work together to contribute to each other in order to realize Islamic economic goals. The contribution of each stakeholder in the banking sector has been researched a lot, and has a significant influence on various objectives.

Siringoringo (2012) conducted a study of the factors that influence the bank intermediary function. The factors examined are capital structure and bank characteristics which include profitability, bank size, credit risk, management burden. While the bank intermediary function is measured by the amount of credit disbursement by banks. The results of the study using path analysis techniques stated that the ownership structure and characteristics of the bank affect simultaneously the bank intermediation function. Partially, the effect of capital or equity on lending is higher than the source of funds from debt.

The depositor is one of the stakeholders who entrust funds to the bank to be distributed to fund users. In Islamic banks, depositors save their funds with wadiah contracts and mudharabah contracts. By using the wadiah contract, the depositors do not expect bank profit sharing, because depositors only deposit their money with the bank, and request it again if they need it. While the mudharabah depositor expects profit sharing from the bank's profits, and bear a loss, if the bank suffers a loss. Several studies have been conducted to examine the contribution of depositors in the form of third party funds both on loans to conventional banks and on profit and loss sharing financing in Islamic banks. John (2014), Amelia and Fauziah, (2017) and Othman and Masih (2015) examine depositor contributions to loans or financing. The results of their studies show that this contribution has a positive and significant effect on credit or financing of variables that are thought to affect mudarabah and musharakah financing.

The Shari'ah Supervisory Board is one of the stakeholders listed in the organizational structure of Islamic banks and conventional banks that have a shari'ah business unit. The Shari'ah 
Do Contributions of Islamic Banks Stakeholders Influence Profit and Loss Sharing Financing? : Empirical Evidence in Indonesia

Supervisory Board has a function to ensure compliance with certain bank shari'ah. The Shari'ah Supervisory Board also functions to determine shari'ah-compliant products and services. Alman (2013) examined the effect of the composition of the shari'ah supervisory board on the behavior of Islamic banks in loan risk taking. The results of the study show that there is an effect of the composition of the shari'ah supervisory board on the behavior of Islamic banks in taking the risk of lending.

The various problems that may be faced by banks in implementing profit and loss sharing can be ignored if Islamic banks have a strong management commitment. Several studies regarding the influence of management commitment to various business objectives have been carried out. The results of the studies (Cooper (2006); Keramati and Azadeh (2007); Tzempelikos (2015); Babakus et al. (2003); Javed (2015); Caroline, Harriet and Anne (2016)) have proven that management commitment is able to drive achievement various goals.

Research on management commitment and its effect on financing at Islamic banks is carried out qualitatively. Indicators of management commitment obtained from secondary data are still very rarely used.

\section{Methodology}

\subsection{Scope of Research}

This research was conducted at all Islamic Commercial Banks and Shari'ah Business Units in Indonesia. This research was conducted by observing the contribution of investor stakeholders, wadiah depositors, mudharabah depositor, management and shari'ah supervisory board on profit and loss sharing financing. This data was collected from the annual report of Islamic Commercial Banks and Conventional Banks that have Shari'ah Business Units issued through each bank website starting from 2011 to 2017.

\subsection{Types and Data Sources}

The data used for this study is secondary data. These data are obtained from Indonesian Banking Statistics published by the Financial Services Authority, annual reports of all Islamic Commercial Banks and annual reports of conventional banks that have Shari'ah Business Units. The data collected is data published from 2011 to 2017.

\subsection{Data collection techniques}

Data collection techniques used in this study are documentation of annual report documents for Islamic commercial banks and conventional banks that have a shari'ah business unit in Indonesia from 2011 to 2017. From 34 commercial banks and sharia business units there were only 25 banks that had been established and presented their annual reports for seven consecutive years. The data were obtained at each banking website.

\subsection{Variable operationalization}

The variables used in this study include the five dependent variables and the one independent variable. The meaning of these variables can be explained in the following table: 
Table 2: Variable operationalization

\begin{tabular}{|l|l|l|}
\hline Variables/ references & Indicator & Scale \\
\hline Investor Contribution & The amount of capital & Ratio \\
\hline $\begin{array}{l}\text { Depositor } \\
\text { wadiah contract }\end{array}$ & $\begin{array}{l}\text { The amount of third party funds deposited with } \\
\text { shari'ah commercial banks and shari'ah business units } \\
\text { using the wadiah agreement. }\end{array}$ & Ratio \\
\hline $\begin{array}{l}\text { Depositor } \\
\text { Contribution in } \\
\text { mudharabah contract }\end{array}$ & $\begin{array}{l}\text { The total amount of third party funds with } \\
\text { mudharabah contract, consisting of deposits and } \\
\text { mudarabah savings }\end{array}$ & Ratio \\
\hline $\begin{array}{l}\text { Management } \\
\text { contribution }\end{array}$ & $\begin{array}{l}\text { Management commitment is reflected in the training } \\
\text { and communication of profit and loss sharing } \\
\text { financing }\end{array}$ & Ratio \\
\hline $\begin{array}{l}\text { Shari'ah Supervisory } \\
\text { Board Contribution }\end{array}$ & $\begin{array}{l}\text { Index on the number of members of the Shari'ah } \\
\text { Supervisory Board, membership in other Islamic } \\
\text { banks, educational qualifications, academic reputation } \\
\text { and expertise of the Shari'ah Supervisory Board as } \\
\text { well as the frequency of meetings. }\end{array}$ & Ratio \\
\hline $\begin{array}{l}\text { Profit and loss } \\
\text { sharing Financing }\end{array}$ & \begin{tabular}{l} 
Mudharabah and Musharakah Financing \\
\hline
\end{tabular}
\end{tabular}

The regression model for this study is as follows:

PLS

$$
=\mu_{0}+\mu_{1} \mathrm{Mo}+\mu_{2} \mathrm{DpkM}+\mu_{3} \mathrm{DpkW}+\mu_{4} \mathrm{KM}+\mu_{5} \mathrm{DPS}+\varepsilon
$$

In which PLS is Profit and Loss Sharing Financing, $\mu_{0}$ is constants, $\mu_{1}-\mu_{5}$ is a coefficient, Mo is investor contribution, DpkM is a contribution of mudharabah depositors, DpkW is a contribution of wadiah depositors, $\mathrm{KM}$ is a management contribution in the form of management commitment, DPS is a contribution shari'ah supervisory board, and $\varepsilon$ is an error.

\section{Result and Discussion}

\subsection{Test the validity of the model}

Validity test of classical assumptions is done to test the accuracy of a model (goodness of fit model) from the estimation results of the regression model used. The test is related to the presence or absence of problems in the regression model, namely normality, multicollinearity, heterocedasticity and autocolrelation. This test is done to obtain accuracy and certainty that the estimation of the regression model meets the requirements of best, linear, unbiased estimation, BLUE estimation assumptions. 


\subsection{Normality test}

The purpose of the normality test is to determine whether the residuals of each equation are normally distributed according to the assumption of the BLUE regression. If p-value on the results of the normality test for profit and loss sharing model is greater than 0.05 , then this equation is declared normal. The results of the normality profit and loss sharing financing pvalue test is 0.85 , so that the data in this equation can be said to be normal.

\subsection{Multicollinearity Test}

Multicollinearity test is a test to find out is there a strong relationship between two variables in the regression equation model. Multicollinearity can be tested by looking at the value of Variance Inflating Factor (VIF). If the VIF value is less than 10, then the model is free of multicollinearity. The VIF value of each variable in the equation of profit and loss sharing ranges from 1 to 7.8 . Thus the model of profit and loss sharing sharing is free from multicollinearity.

\subsection{Autocorrelation Test}

The autocorrelation test aims to test whether in the linear regression model there is a correlation between the interfering error in period $t$ and the confounding error in the period $t$ 1. The method often used is the Durbin Watson method. If the DW value is greater than DU, it can be concluded that there is no autocorrelation in this model. The autocorrelation test results show that the DW value of 1,895 is greater than the DU value of 1.8024 . This result shows that there is no autocorrelation in this regression model.

\subsection{Regression Result}

The results of this study show that the value of adjusted $\mathrm{R}^{2}$ in profit and loss sharing financing model is $80.13 \%$. This means $80.13 \%$ change in profit and loss sharing financing can be explained by stakeholders contribution variables, while $19.87 \%$ is influenced by other variables not included in this model.

The test results show a positive influence between the contribution of wadiah depositors and mudharabah depositors to profit and loss sharing financing at a significance level of $5 \%(\mathrm{p}=$ 0.02 and $p=0.000$ ). The test results also show a positive influence between management contributions through management commitment at a $5 \%$ significance level $(p=0.01)$. It means that depositors and management contribute to increase profit and loss sharing financing.

Several other variables, namely investor contributions are partially proven to have no real influence at the $5 \%$ significance level $(p=0.27)$. Likewise, the contribution of the shari'ah supervisory board proved partially to have no real influence at the $5 \%$ significance level $(\mathrm{p}=$ $0.90)$. 
Table 3: Estimated Result of Profit and Loss Sharing Financing Model

$\begin{array}{ll}\text { Dependent Variable } & : \text { PLS } \\ \text { Method } & : \text { Least Square } \\ \text { Sample } & : 1175 \\ \text { Sample Observation } & : 175\end{array}$

\begin{tabular}{ccccc}
\hline Variable & Coefficient & Std. Error & t-Statistic & Probability \\
C & -2.831786 & 5.938835 & -0.476825 & 0.6341 \\
MO & -0.148047 & 0.134227 & -1.102960 & 0.2716 \\
DPKW & 0.277462 & 0.119060 & 2.330438 & 0.0210 \\
DPKM & 0.442633 & 0.058128 & 7.614773 & 0.0000 \\
KM & 1.690233 & 0.672855 & 2.512031 & 0.0129 \\
DPS & 0.124627 & 1.047974 & 0.118922 & 0.9055 \\
\hline R-squared & & & & 0.807083 \\
Adjusted R-Squared & & & & 0.801375 \\
F-Statistic & & & & 141.4045 \\
Prob F-Statistic & & & & 0.000000
\end{tabular}

Source: Analysis results

The results of this study explain that all stakeholders of Islamic banks can work together to achieve the objectives of Islamic banking. All stakeholders contribute through the resources they have, so that Islamic banks can increase profit and loss sharing financing. The results of this study are in line with the theories used. In detail, the results of this study are in line with the stakeholder theory introduced by Freeman (1984). The Bank involves all stakeholders in providing the best products of Islamic banks. The results of this study also support the Shari'ah enterprise theory introduced by Triyuwono (2007). This theory explains that humans are asked to become caliphs who can improve the welfare of the people. Islamic banks implement the request by distributing profit and loss sharing financing, although this financing is deemed risky financing.

Partially, the results of the study indicate that the contributions of mudharabah and wadiah depositors third party funds have a positive effect on profit and loss sharing financing. This research is in line with several studies conducted both in conventional banks and Islamic banks. Changes in third party funds to conventional banks affect changes in the amount of loans disbursed (John (2014). The results of this study are in line with the results of research conducted on Islamic banks ( Othman and Masih (2015); Kholid and Bachtiar (2015)).

The results of this study also state that management's contribution to Islamic banks in the form of management commitment affects profit and loss sharing financing partially. This 
Do Contributions of Islamic Banks Stakeholders Influence Profit and Loss Sharing Financing? : Empirical Evidence in Indonesia

phenomenon is in accordance with the results of research conducted by Keramati and Azadeh (2007). The indicator of management commitment in this study also refers to the Keramati and Azadeh (2007) research, namely training and communication as a proxy for management commitment.

The results of this study are also in line with the results of Ascarya's research (2010) which used the Analytic Network Process approach. Ascarya (2010) explained that one of the causes of lack of distribution of profit and loss sharing financing is the low management commitment. The results also corroborate the results of several other research studies on management commitment (Tzempelikos (2015), Babakus, 2003; Caroline, Harriet and Anne, 2006) which stated that management commitment has a positive effect on management's success in implementing corporate objectives.

Statistical analysis obtained from the results of this study not only supports previous research and theories, but also shows results that are not in line with some previous studies. The results of the study are partial, showing that capital does not have a real influence on profit and loss sharing financing ( $p$ value $=0.27$ ). The results of this study are certainly not in line with the results of the research of several previous researchers (Berrospide and Edge (2010); Karmakar and Mok (2013); Siringoringo (2012)). The difference between this study and previous research lies in the form of financing provided. The object of the three previous studies is conventional banks that provide interest loans. While in this study the shared financing is profit and loss sharing financing. When compared between this study and previous research, the difference becomes reasonable, because the credit affected by capital in the study is credit that prioritizes interest.

This difference may be the cause of differences in the direction of capital influence and financing compared to the effect of financing with credit. The results of the study show that capital has a negative, but not significant effect on this financing. The greater the capital owned by the bank, the smaller the profit and loss sharing financing.

Nevertheless, the results of this study are in line with the results of Rahman and Nor's (2016) study. Research conducted on two Islamic banks in Malaysia stated that profit and loss sharing financing is a high-risk financing. Banks are still very concerned about the security of capital channeled to partners or customers who use the funds. The bank still does not get an adequate capital security guarantee from this financing distribution. Banks continue to channel the funds they have and choose safer financing such as murabahah financing.

Two other variables analyzed in this model are depositor contributions in wadiah third party funds and the role of the shari'ah supervisory board. The results of this study are not in line with the results of research conducted by John (2014) which explains that third-party funds generally contribute to lending. The contradiction of the results of this study with John's research (2014) precisely strengthens Febianto's (2012) statement which states that profit and loss sharing financing is a unique financing, which is different from credit in conventional banks. 
The second variable in this study that has no real influence on profit and loss sharing financing is the variable role of the shari'ah supervisory board. The results of this study support the results of Dusuki's research (2008) which explains that the shari'ah supervisory board prioritizes the continuity of Islamic banking business rather than maintaining the ideal product of Islamic banks. In carrying out its duties the shari'ah supervisory board places more emphasis on shari'ah compliance, so the shari'ah supervisory board does not place too much emphasis on profit and loss sharing financing. Other financing such as murabahah, ijarah, istisna, and salam financing are also halal financing. The shari'ah supervisory board does not impose shari'ah commercial banks and shari'ah business units to carry out profit and loss sharing financing.

The results of this study as a whole indicate that Islamic commercial banks and Islamic business units must be supported by large third party funds with high management commitment to make Islamic banks an ideal bank. The results of this study also indicate that Islamic banks really need the support of depositors to realize the vision of Islamic economics that wants to improve the welfare of the people in the real sense.

\section{Conclusion}

Based on the background, formulation of the problem, the development of hypotheses and related theories and the results of data analysis that have been discussed in previous chapters, the conclusions of this study are as follows:

1. The contribution of all stakeholders both through capital, mudarabah third party funds, wadiah third party funds, the role of the shari'ah supervisory board, management commitment to a positive and significant effect simultaneously on profit and loss sharing financing. This shows the greater capital, wadiah third party funds, mudarabah third party funds, the role of the shari'ah supervisory board, and management commitment, the greater the profit and loss sharing financing channeled by shari'ah commercial banks and shari'ah business units.

2. Contribution Mudharabah depositors and wadiah depositors to Islamic banks in Indonesia through their third party funds and management contributions in management commitments have a positive and significant influence on profit and loss sharing financing partially.

3. The limitation of this study is profit and loss sharing financing cannot be explained in more detail in the mudharabah and musharakah contract classifications, this is because data is not available in published financial statements. Only a small number of banks publish mudharabah and musharakah financing separately. 
Do Contributions of Islamic Banks Stakeholders Influence Profit and Loss Sharing Financing? : Empirical Evidence in Indonesia

\section{References}

Abduh, M., \& Omar, M. A. (2012). Islamic banking and economic growth : the Indonesian experience. International Journal of Islamic and Middle Eastern Finance and Management, 5(1), 35-47. https://doi.org/10.1108/17538391211216811

Agriyanto, R. (2015). Redefining Objective of Islamic Banking; Stakeholders Perspective in Indonesia. Economica, VI(June 2014), 77-90. https://doi.org http://journal.walisongo.ac. id /index.php/economica/article/view/795/705

Ahmed, H. I., Akbar, S., \& Barikzai, K. (2016). Objectives of Islamic Finance achieved by Islamic Banks. Al-Adwa, 45(31), 45-65.

Alman, M. (2012). Shari'ah Supervisory Board Composition Effects On Islamic Banks ' RiskTaking Behavior Shari ' ah Supervisory Board Composition Effects On Islamic Banks ' Risk-Taking Behavior. Journal of Banking and Regulation, 82, no.1, 1-43.

Al-shamali, F. A., Sharif, A., \& Irani, Z. (2013). Islamic Banking Reinterpretation of The Stakeholder Theory. Arabian Journal of Business and Management Review, 3(2), 63-72.

Amelia, E., \& Fauziah, H. E. (2017). Determinant of Mudharabah Financing: A Study at Indonesian Islamic Rural Banking. Etikonomi, 16(1), 43-52. https://doi.org/10.15408/etk.v16i1.4638

Ascarya. (2010). The Lack of Profit and Loss Sharing Financing in Indonesia's Islamic Banks: Revisited. Review of Indonesia of Economic and Business Sudy, 1(1), 1-15.

Ascarya, \& Yumanita, D. (2005). Mencari solusi rendahnya pembiayaan bagi hasil di perbankan syariah indonesia. Buletin Ekonomi Moneter Dan Perbankan, juni, 7-43.

Azmat, Saad, Skully, Michael and Brown, Kym, (2015), Can Islamic banking ever become Islamic?, Pacific-Basin Finance Journal, 34(C), 253-272.

Babakus, E., Yavas, U., Karatepe, O. M., \& Avci, T. (2003). The Effect of Management Commitment to Service Quality on Employees $\hat{\mathrm{a}} €^{\mathrm{TM}}$ Affective and Performance Outcomes. Journal of the Academy of Marketing Science, 31(3), 272-286. https://doi.org/ $10.1177 / 0092070303253525$

Bakar, Mohd Daud and Ali, E.R.A. Engku. (2008) Essential Reading in Islamic Finance, Kuala Lumpur: CERT Publication Sdn. Bhd

Berrospide, J. M., \& Edge, R. M. (2010). The Effects of Bank Capital on Lending: What Do We Know, and What Does It Mean? International Journal of Central Banking, 6(4), 1-50. 
Caroline, N., Harriet, K., \& Anne, N. (2016). Top Management Commitment for Successful Small and Medium-Enterprises ( SMEs ): A Hoax or A Reality? European Scientific Journal, 12(4), 259-268. https://doi.org/10.19044/esj.2016.v12n4p259

Chong, S., \& Liu, M. (2009). Islamic banking: Interest-free or interest-based ? 弥. Pacific-Basin Finance Journal, 17(1), 125-144. https://doi.org/10.1016/j.pacfin.2007. 12.003

Cooper, D. (2006). The Impact of Management's Commitment on Employee Behavior : A Field Study. In 7th Professional Development Conference \& Exhibition (Vol. 1, pp. 1-8).

Donaldson, T., Preston, L. E., Donaldson, T., \& Preston, L. E. E. E. (1995). Theory The Stakeholder Of The Concepts , Evidence, Corporation: And Implication. Academy of Management Review, 20(1), 65-91.

Dusuki, A. W. (2008). Understanding the objectives of Islamic banking: a survey of stakeholders ' perspectives. International Journal of Islamic and Middle Eastern Finance and Management, 1(2), 132-148. https://doi.org/10.1108/17538390 810880982

Farooq, M., \& Ahmed, M. M. M. (2013). Musharakah financing: Experience of Pakistani banks. World Applied Sciences Journal, 21(2), 181-189. https: //doi.org/ 10.5829 /idosi.wasj. 2013.21.2.2387

Febianto, I. (2012). Adapting Risk Management for Profit and Loss Sharing Financing of Islamic Banks. Modern Economy.

Freeman, R. E. (1984). Strategic Management: A stakeholder approach. Boston: Pitman.

Freeman, R.E. (2002). "Stakeholder Theory of the Modern Corporation", in T. Donalson and P. Werhane (eds), Ethical Issues in Business: A Philosophical Approach, 7th Edition (Prentice Hall, Englewood Cliffs, NJ), pp. 38-48

Freeman, R.E. et.al. (2010) Stakeholder Theory: The State of the Art, Newyork: Cambridge University Press

Hamza, H. (2013) Sharia Governance in Islamic Banks: Effectiveness and Supervision Model. International Journal of Islamic and Middle Eastern Finance and Management, 6(3), pp.226-237

Handayati, P., Krisnawati, D., Soetjipto, B. E., Sudarmiatin, \& Suharto. (2017). The shari'ahh Enterprise Theory: Implementation of Corporate Social Responsibility Disclosure for Islamic Banking in Indonesia and Malaysia. International Journal of Economic Research, 14(13), 195-206. 
Do Contributions of Islamic Banks Stakeholders Influence Profit and Loss Sharing Financing? : Empirical Evidence in Indonesia

Hanif, M., \& Iqbal, Ab. M. (2010). Islamic Financing and Business Framework: A Survey. European Journal of Social Sciences, 15(4), 1-18.

Javed, S. (2015). Impact of Top Management Commitment on Quality Management. International Journal of Scientific and Research Publication, 5(8), 1-5.

Jaurino, \& Wulandari, R. (2017). The Effect of Mudharabah and Musharakah on The Profitability of Islamic Banks. In 3rd Parahyangan International Accounting \& Business Conference (pp. 69-84). Bandung.

Jensen, M. C., \& Meckling, W. H. (1976). Theory of The Firm: Managerial Behavior, Agency Cost and Ownership Structure. Journal of Financial Economics, 3, 305-360.

John, A. O. (2014). Effect of Deposit Volume on Banks' Lending Behaviour in the Nigerian Post-Consolidation Era. International Journal of Innovation and Scientific Research, 4(1), 2125.

Kalbarini, R. Y., \& Suprayogi, N. (2014). Implementasi Akuntabilitas dalam Konsep Metafora Amanah di Lembaga Bisnis Syariah. JESTT, 1(7), 506-517.

Karmakar, S., \& Mok, J. (2013). Bank Capital And Lending : An Analysis Of Commercial Banks In The United States. Portugal.

Khan, S. R. (1983). Profit and Loss Sharing: An Economic Analysis Of An Islamic Financial System. The University of Michigan.

Kholid, M.N and Bachtiar, A. (2015). Good Corporate Governance dan Kinerja Maqasid Syariah. Jurnal Akuntansi \& Auditing Indonesia, 19(2). pp.126-136

Kurniawati, M., \& Yaya, R. (2017). Pengaruh Mekanisme Corporate Governance, Kinerja Keuangan dan Kinerja Lingkungan terhadap Pengungkapan Islamic Social Reporting. Jurnal Akuntansi Dan Investasi, 18(2), 163-171. https://doi.org/10.18196/jai.180280

Meutia, I., Sudarma, M., Triyuwono, I., \& Ludigdo, U. (2010). Qualitative Approach to Build the Concept of Social Responsibility Disclosures Based on Shari'ah Enterprise Theory. Master of Business Administration, 18(6), 16-43. https://doi.org/10.2139 /ssrn.1662860

Novarela, D., \& Sari, I. M. (2015). Pelaporan Corporate Social Responsibility Perbankan Syariah dalam Perspektif Syariah Enterprise Theory. Jurnal Akuntansi Dan Keuangan Islam, 2(2), 145-160.

Othman, A. N., \& Masih, M. (2015). Do profit and loss sharing (PLS) deposits also affect PLS financing? Evidence from Malaysia based on DOLS, FMOLS and system GMM techniques. Kuala Lumpur. 
Rosly, S. A. (2005). Islamic Banking: Doing Things Right and Doing Right Things. Malaysian Journal of Economic Studies, 42(1/2), 31-40.

Saad, N. M., \& Razak, D. A. (2013). Towards An Application of Musharakah Mutanaqisah Principle In Islamic Microfinance, 14(2), 221-234.

Siddiqui, A. (2008). Financial contracts, risk and performance of Islamic banking. Managerial Finance, 34(10), 680-694. https://doi.org/10.1108/0307435081089 1001

Siringoringo, R. (2012). Karakteristik dan Fungsi Intermediasi Perbankan di Indonesia. Buletin Ekonomi Moneter Dan Perbankan, 61-84.

Triyuwono, Iwan. 2007. Perspektif, Metodologi dan Teori Akuntansi Syariah. Jakarta: PT. Rajagrafindo Persada.

Tzempelikos, N. (2015). Top Management Commitment and Involvement and Their Link to Key Account. Journal of Business $\mathcal{E}$ Industrial Marketing, 30(1), 32-44. https://doi.org/10.1108/JBIM-12-2012-0238 